\section{Field Evaluation of Carbon Sources for Anaerobic Soil Disinfestation in Tomato and Bell Pepper Production in Tennessee}

\author{
D. Grant McCarty II and Sarah E. Eichler Inwood \\ Department of Plant Sciences, University of Tennessee, 2431 Joe Johnson \\ Drive, Knoxville, TN 37996
}

\author{
Bonnie H. Ownley \\ Department of Entomology and Plant Pathology, University of Tennessee, \\ 2505 E.J. Chapman Drive, Knoxville, TN 37996
}

\author{
Carl E. Sams, Annette L. Wszelaki, and David M. Butler ${ }^{1}$ \\ Department of Plant Sciences, University of Tennessee, 2431 Joe Johnson \\ Drive, Knoxville, TN 37996
}

Additional index words. biofumigation, biological soil disinfestation, Capsicum annum, cover crops, Rhizoctonia solani, Solanum lycopersicum, molasses

\begin{abstract}
Anaerobic soil disinfestation (ASD) is a biologically based, non-fumigant, preplant soil treatment developed to control soilborne plant pathogens and plant-parasitic nematodes in specialty crop production systems. Soil treatment by ASD includes the incorporation of a labile carbon (C) source, tarping with plastic, and irrigation of the topsoil to saturation $(5 \mathrm{~cm}$ irrigation) to create conditions conducive to anaerobic decomposition of the added $\mathrm{C}$ source. A field study was implemented beginning in Fall 2010 and repeated in the same plot locations in Fall 2011 in Knoxville, TN, to evaluate ASD. Soil properties, weed and Rhizoctonia solani population dynamics, and crop performance were evaluated after ASD treatment with several potential $C$ sources for ASD before production of fresh-market tomato (Solanum lycopersicum L. 'Red Defender') and red bell pepper (Capsicum annum L. 'Red Knight X3R'). Treatments included: 1) untreated control; 2) mustard seed meal (biofumigant control); 3) ASD with dried molasses; 4) ASD with soil-incorporated Indian mustard (Brassica juncea L.), white mustard (Sinapis alba L.), and arugula (Eruca sativa Mill.) cover crop with molasses added at cover crop incorporation; 5) ASD with soil-incorporated Indian mustard, white mustard, and arugula cover crop; 6) ASD with soil-incorporated cereal rye (Secale cereale L.) cover crop with molasses added at cover crop incorporation; and 7) ASD with soil-incorporated cereal rye cover crop. Accumulated soil anaerobic conditions were significantly greater than the untreated control in all ASD treatments except the ASD mustard/arugula treatment. Although not related to accumulated anaerobic conditions, populations of $R$. solani were lowest and equivalent to the biofumigant control for ASD cereal rye and ASD mustard/arugula treatments. Differences in weed populations and soil inorganic nitrogen among treatments were limited. Yield of bell pepper and tomato did not differ among treatments, which may have been partly the result of the low pest pressure observed at the site over the 2 years of the study.
\end{abstract}

Many vegetable, small fruit, and ornamental producers are transitioning from the use of methyl bromide (MeBr) as a pre-plant soil fumigant. This is largely the result of the global phase-out of this ozone-depleting chemical as part of the Montreal Protocol (UNEP, 1987) as well as increased costs for a reduced supply of available $\mathrm{MeBr}$. Because there are limitations of alternative chemical soil fumigants, many growers would be amenable to implementing a non-chemical approach to soil disinfestation if comparable crop yields and control of soilborne plant pathogens, plant-parasitic nematodes, and weeds could be achieved. The use of ASD is one non-chemical approach that has shown promise in Japan, The Netherlands, Florida, and California (Butler et al., 2012a, 2012b;
Goud et al., 2004; Momma et al., 2006; Shennan et al., 2011). Soil treatment using ASD involves incorporation of an easily decomposable $\mathrm{C}$ source, covering the soil with plastic, and then irrigating the topsoil to field capacity. This method is also compatible with U.S. Department of Agriculture (USDA) National Organic Program standards for certified organic production. Amendments used can vary but must contain an adequate supply of labile $\mathrm{C}$ to support soil microbial growth during a treatment period ranging from 2 to 6 weeks in length (Momma, 2008). During ASD treatment, organic acids, particularly acetic and $n$-butyric acids, are released into the soil solution as the C source decomposes anaerobically (Momma, 2008).
In early ASD research in The Netherlands (where this soil treatment is often referred to as biological soil disinfestation), several researchers examined impacts of ASD treatment using fresh grass or crop residues as a $\mathrm{C}$ source on soilborne pathogens of concern. Blok et al. (2000) reported that incorporated amendments (i.e., labile $\mathrm{C}$ source) and mulching with a polyethylene film were both necessary for mortality of Verticillium dahliae Kleb. and Rhizoctonia solani Kühn inoculum. Similarly, Goud et al. (2004) reported an $85 \%$ reduction in inoculum density of endemic $V$. dahliae compared with an unamended, uncovered control and in a field study Messiha et al. (2007) reported a decline in Ralstonia solanacearum survival rates after ASD treatment.

In Japan, the use of wheat bran as a C source in ASD demonstrated potential for reducing disease severity of bacterial wilt (R. solanacearum) on tomato (Momma, 2008) and conidia and chlamydospores of Fusarium oxysporum Schlechtend.:Fr. (Momma et al., 2005). The presence of both acetic and butyric acids during the anaerobic decomposition of wheat bran during ASD treatment and resulting reductions in soil $\mathrm{pH}$ was reported by Momma et al. (2006). Subsequent assays indicated that $R$. solanacearum was completely suppressed by organic acids added to soils at levels representative of that observed during ASD treatment, but $F$. oxysporum f. sp. lycopersici was less sensitive to the organic acids (Momma et al., 2006). Although organic acids play a role in pathogen suppression during ASD treatment, there are a number of interacting and counteracting variables in the field that must be considered. A recent examination of the organic acids released during ASD treatment with ethanol as a $\mathrm{C}$ source also noted the presence of the metal ions $\mathrm{Fe}^{2+}$ and $\mathrm{Mn}^{2+}$ when soil reduction occurred and it was hypothesized that this may also play a role in suppression of $F$. oxysporum during ASD treatment (Momma et al., 2011).

Studies in Florida have also shown promising results in the ability of ASD to control pests when combined with soil solarization (covering moist soil with transparent polyethylene to increase soil temperatures to control certain pathogens and weeds). Liquid molasses ( $1.1 \mathrm{mg} \mathrm{C} / \mathrm{g}$ soil) as a $\mathrm{C}$ source for ASD treatment combined with solarization significantly increased mortality of $F$. oxysporum inoculum to levels comparable with a fumigated $\mathrm{MeBr}$ control (Butler et al., 2012a). By the end of the study, populations of Meloidogyne incognita (Kofoid \& White) Chitwood and ratings of root galling on eggplant (Solanum melongena $\mathrm{L}$.) were equivalent to the $\mathrm{MeBr}$ control and less than solarization alone when molasses was used as an amendment in ASD treatment (Butler et al., 2012a). In a greenhouse pot study of ASD treatment with various warm-season legume and grass cover crops, introduced $F$. oxysporum inoculum was reduced by $97 \%$ when a $\mathrm{C}$ source was added compared with the control (no C source), whereas Sclerotium rolfsii Sacc. was 
inconsistently affected by C source and ASD treatment (Butler et al., 2012b). In the same study, mortality of yellow nutsedge (Cyperus esculentus $\mathrm{L}$.) tubers was greatest when molasses was used as a $\mathrm{C}$ source $(31 \%$ germination vs. $76 \%$ germination in the control).

Although a number of studies have reported the impact of ASD treatments on soilborne pathogens and parasitic nematodes, published data on the impact of ASD treatments on soil properties, crop yields, and weed control are limited. The lack of information on soil nutrient dynamics with ASD treatment is important considering that available nitrogen (N) may substantially increase or decrease with treatment depending on $\mathrm{C}$ source amendment rates and properties and treatment impact on soil microbial communities (such as nitrifying bacteria) important in nutrient cycling processes. Without further evaluation of these issues, practitioners and researchers will not have adequate information to implement ASD treatments and manage production systems to account for differences in soil fertility compared with standard practices (both chemical and non-chemical).

The objectives of this field study were to 1) evaluate accumulated anaerobic soil conditions (as indicated by soil redox potential) and soil properties after ASD treatment with a range of $\mathrm{C}$ sources; 2) evaluate weed emergence and populations of endemic $R$. solani among ASD treatments; and 3) evaluate productivity of tomato and bell pepper crops after ASD treatments.

\section{Materials and Methods}

A randomized complete block design including five $\mathrm{C}$ sources for ASD treatment and two controls was established with four replicates (blocks) at the East Tennessee Agricultural Research and Education Center in Knoxville, TN, beginning in Fall 2010 and treatments repeated on the same treatment plot locations in Fall 2011. The experimental area is USDA-certified organic and had been cropped with a diverse mix of vegetables

Received for publication 25 Nov. 2013. Accepted for publication 25 Dec. 2013

Funding provided by USDA-NIFA Methyl Bromide Transitions grant 2010-51102-21707 and the Tennessee Agricultural Experiment Station.

Mention of a trademark, proprietary product, or vendor is provided for reader information only and does not constitute an endorsement or warranty of the product by the authors or the University of Tennessee.

We gratefully acknowledge the technical assistance provided by Mary Dee, Mary Rogers, Jeff Martin, Bobby Simpson, Lee Ellis, Bill Lively, Bobby Terry, Ali Lieb, Hannah Barry, Cody Fust, and Jordan Norton. Erin Rosskopf and Nancy Kokalis-Burelle provided comments which improved the manuscript. Mustard and arugula cover crop seed was donated by High Performance Seed, Moses Lake, WA.

This paper is part of a M.S. thesis submitted by D.G. McCarty II.

${ }^{1}$ To whom reprint requests should be addressed; e-maildbutler@utk.edu. during the growing seasons immediately before this study. The site was chosen from available research sites as a result of a history of vegetable production and potential for pressure by weeds, soilborne disease, or other minor root pathogens or deleterious rhizosphere microorganisms. The soil was a Dewey clay loam (fine, kaolinitic, thermic, typic Paleudult) with initial soil organic $\mathrm{C}$ content of $1.1 \mathrm{~g} \mathrm{C} / \mathrm{kg}$ soil. In Fall 2010, stockpiled poultry (broiler) litter was applied to all plots at a rate of $4.5 \mathrm{Mg} \cdot \mathrm{ha}^{-1}(28 \%$ moisture content; $1.1 \mathrm{Mg} \mathrm{C} / \mathrm{ha}, 34 \mathrm{~kg} \mathrm{~N} / \mathrm{ha}, 53 \mathrm{~kg}$ phosphorus/ha, $67 \mathrm{~kg}$ potassium/ha) and incorporated to increase soil phosphorus $(\mathrm{P})$ and potassium $(\mathrm{K})$ levels and support cover crop growth. In Fall 2011, poultry litter was again applied to all plots at a rate of $4.5 \mathrm{Mg} \cdot \mathrm{ha}^{-1}(43 \%$ moisture content; $0.88 \mathrm{Mg} \mathrm{C} / \mathrm{ha}, 125 \mathrm{~kg} \mathrm{~N} / \mathrm{ha}$, $56 \mathrm{~kg} \mathrm{P} / \mathrm{ha}, 51 \mathrm{~kg} \mathrm{~K} / \mathrm{ha}$ ). Each treatment was established in a plot $2.4 \mathrm{~m} \times 9.1 \mathrm{~m}$. Treatments included: 1) a fallow, unamended control ("untreated control"); 2) fallow with mustard seed meal added at treatment ("biofumigant control"); 3) fallow with dried molasses added for ASD treatment; 4) ASD treatment with a commercial mixture ('Caliente 61') of Indian mustard (Brassica juncea L.) and white mustard (Sinapis alba L.) seeded in a 1:1 mixture with arugula (Eruca sativa Mill. 'Nemat') with a lower rate of dried molasses than in Treatment 3 added at cover crop incorporation; 5) ASD treatment with the same commercial mustard and arugula cover crop mixture like in Treatment 4 but with no molasses amendment; 6) ASD treatment with a cereal rye (Secale cereale L., variety not stated) cover crop with a lower rate of dried molasses added at cover crop incorporation; and 7) ASD treatment with a cereal rye cover crop seeded at the same rate as in Treatment 6 with no molasses amendment. Detailed information on cover crops and amendments used in each treatment are listed in Table 1 and amendment properties given in Table 2 and 3. Poultry litter amendment properties are not included in Table 1,2, and 3 because applications were equivalent across all treatments in the fall of each season before amendment and cover crop incorporation in spring. Cover crops for Treatments 4, 5, 6, and 7 were drilled (Light Duty Grain Drill; ALMACO, Nevada, Iowa) on 27 Sept. 2010 and again on Oct. 26, 2011, whereas all other plots remained fallow during the fall and winter of both seasons.

All treatments containing a cover crop were flail mowed (SH74 Flail Mower; Alamo Industrial, Seguin, TX) on 7 Apr. 2011 and on 28 Mar. 2012. Molasses and mustard seed meal amendments were evenly applied by hand to a strip $(1.8 \mathrm{~m} \times 9.1 \mathrm{~m})$ along the center of respective treatment plots. All plots except the biofumigant control had feather meal applied to about standardize the amount of added total $\mathrm{N}$ in each amendment mixture (target $130 \mathrm{~kg}$ total N/ha) based on estimates of amendment total $\mathrm{N}$ content (irrespective of cover crop biomass $\mathrm{N}$ ) and to prevent large treatment differences in $\mathrm{N}$ fertility posttreatment. Actual $\mathrm{N}$ content of amendments sampled at treatment differed slightly from estimated values leading to a range of total $\mathrm{N}$ values in soil amendments at 109 to $161 \mathrm{~kg}$ $\mathrm{N} /$ ha (Tables 2 and 3). Plots were rotovated (RTC240; Bush Hog, Inc., Selma, AL) immediately after amendments were applied to $\approx 20$-cm depth and beds formed (0.9-m width) and covered with black polyethylene $(0.032-\mathrm{mm}$ embossed; Pliant-Berry Plastics, Evansville, IN). A drip irrigation line $\left(4.2 \mathrm{~L} \cdot \mathrm{min}^{-1}\right.$ flow rate per $100 \mathrm{~m}$; T-Tape; John Deere/TSystems, San Diego, CA) was installed under the polyethylene mulch in the center of each bed as the mulch was applied. Five centimeters of water was applied once to all beds at the initiation of treatment based on the calculated amount of water needed to fill soil pore space with water to a depth of $\approx 20 \mathrm{~cm}$.

Soil and cover crop samples were collected in Apr. 2011 and Mar. 2012, before the initiation of the ASD treatments. Seven soil cores $(0-$ to $15-\mathrm{cm}$ depth, $1.75-\mathrm{cm}$ internal diameter) were collected from random locations within each plot and composited. A subsample was oven-dried $\left(105^{\circ} \mathrm{C}\right)$ to determine gravimetric moisture content, and the remaining sample was air-dried and sieved (less than $2 \mathrm{~mm}$ ) before further analyses. Soil $\mathrm{pH}$ was determined on air-dried samples in $0.01-\mathrm{M} \mathrm{CaCl}_{2}$ solution $(5 \mathrm{~g}$ soil in $10 \mathrm{~mL}$ solution) using a pH electrode (Orion 3-Star Plus pH Benchtop Meter; Thermo Scientific, Waltham, MA). Soil $\mathrm{pH}$ values are reported as $\mathrm{pH}_{\mathrm{CaCl} 2}+0.6$ to approximate equivalent values of soil $\mathrm{pH}$ determined in suspensions of soil and deionized water (Kissel et al., 2009; Kissel and Vendrell, 2012). To determine soil inorganic N, $5 \mathrm{~g}$ of air-dried soil was extracted with $1-\mathrm{M} \mathrm{KCl}$ for $60 \mathrm{~min}$ on a reciprocating shaker, centrifuged, and filtered (Whatman 42; Whatman Ltd., Kent, U.K.) before colorimetric analysis for $\mathrm{NH}_{4}-\mathrm{N}$ and $\mathrm{NO}_{3}-\mathrm{N}+\mathrm{NO}_{2}-\mathrm{N}$ using a microplate spectrophotometer (Powerwave XS; Biotek, Winooski, VT) as described by Sims et al. (1995). In plots with a cover crop, aboveground biomass was sampled by randomly placing two quadrants $\left(0.25 \mathrm{~m}^{2}\right)$ in each plot and cutting all vegetation within the quadrant at the soil surface. Cover crop samples were weighed and then oven-dried $\left(65^{\circ} \mathrm{C}\right)$ to determine moisture content and total $\mathrm{N}(\mathrm{TN})$ and total C (TC) content by flash combustion (Flash EA 1112 NC Soil Analyzer; Thermo Scientific).

Soil temperature, redox potential, and volumetric soil moisture content were continually monitored and averaged hourly during treatment using soil sensors (combination ORP electrode; Sensorex Corp., Garden Grove, $\mathrm{CA}$, and 5TM soil moisture and temperature sensor; Decagon Devices, Pullman, WA) with an automatic data logging system (CR1000 with AM 16/32 multiplexers; Campbell Scientific, Logan, UT). Each sensor was placed to monitor at a $15-\mathrm{cm}$ soil depth. Raw soil redox potential values were corrected to relate to the redox potential of a standard hydrogen electrode (Fiedler et al., 2007). Anaerobic conditions were indicated based on the soil redox potential, when measured on an average hourly reading, to be below a critical 
Table 1. Cover crop and soil amendments by treatment.

\begin{tabular}{|c|c|c|}
\hline & Cover crops, seeding, rates and source & Soil amendments and source \\
\hline Untreated control & None (winter fallow) & Feather meal, Mason City By-Products, Mason City, IA \\
\hline Biofumigant control & None (winter fallow) & Mustard seed meal, WI Spice, Berlin, WI \\
\hline ASD molasses & None (winter fallow) & $\begin{array}{l}\text { Dried molasses, Westway Feed, Tomball, TX; Feather } \\
\text { meal, Mason City By-Products, Mason City, IA }\end{array}$ \\
\hline ASD mustard/arugula + molasses & $\begin{array}{l}\text { 'Caliente } 61 \text { ' Indian mustard and white mustard, } \\
3.9 \mathrm{~kg} \cdot \mathrm{ha}^{-1} \text {; 'Nemat' arugula, } 3.9 \mathrm{~kg} \cdot \mathrm{ha}^{-1} \text {, High } \\
\text { Performance Seed, Moses Lake, WA }\end{array}$ & $\begin{array}{l}\text { Dried molasses, Westway Feed, Tomball, TX; Feather } \\
\text { meal, Mason City By-Products, Mason City, IA }\end{array}$ \\
\hline ASD mustard/arugula & $\begin{array}{l}\text { 'Caliente } 61 \text { ' Indian mustard and white mustard, } \\
3.9 \mathrm{~kg} \cdot \mathrm{ha}^{-1} \text {; 'Nemat' arugula, } 3.9 \mathrm{~kg} \cdot \mathrm{ha}^{-1} \text {, High } \\
\text { Performance Seed, Moses Lake, WA }\end{array}$ & Feather meal, Mason City By-Products, Mason City, IA \\
\hline ASD cereal rye + molasses & $\begin{array}{l}\text { Cereal rye, } 134 \mathrm{~kg} \cdot \mathrm{ha}^{-1} \text {, Albert Lea Seed House, } \\
\text { Albert Lea, MN }\end{array}$ & $\begin{array}{l}\text { Dried molasses, Westway Feed, Tomball, TX; Feather } \\
\text { meal, Mason City By-Products, Mason City, IA }\end{array}$ \\
\hline ASD cereal rye & $\begin{array}{l}\text { Cereal rye, } 134 \mathrm{~kg} \cdot \mathrm{ha}^{-1} \text {, Albert Lea Seed House, } \\
\text { Albert Lea, MN }\end{array}$ & Feather meal, Mason City By-Products, Mason City, IA \\
\hline
\end{tabular}

$\mathrm{ASD}=$ anaerobic soil disinfestation.

Table 2. Total biomass, carbon (TC) and nitrogen (TN) content, and C:N ratio of soil amendments and incorporated aboveground cover crop biomass, Spring 2011.

\begin{tabular}{|c|c|c|c|c|c|}
\hline & \multicolumn{5}{|c|}{2011} \\
\hline & Biomass $^{z}$ & $\mathrm{TC}^{\mathrm{z}}$ & $\mathrm{TN}^{\mathrm{z}}$ & $\mathrm{TC}^{\mathrm{y}}$ & \multirow[b]{2}{*}{$\mathrm{C}: \mathrm{N}$ ratio ${ }^{\mathrm{x}}$} \\
\hline & \multicolumn{3}{|c|}{ 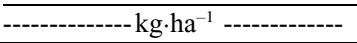 } & $\mathrm{mg} \mathrm{C} / \mathrm{g}$ soil & \\
\hline Untreated control $^{\mathrm{w}}$ & 1,075 & 538 & 161 & 0.21 & 3.3 \\
\hline Biofumigant control & 2,177 & 893 & 109 & 0.35 & 8.2 \\
\hline ASD molasses & 5,993 & 2,243 & 146 & 0.86 & 15.4 \\
\hline Molasses & 5,381 & 1,937 & 54 & 0.74 & 35.9 \\
\hline Feather meal & 612 & 306 & 92 & 0.12 & 3.3 \\
\hline ASD mustard/arugula + molasses & 8,375 & 3,350 & 298 & 1.29 & 11.2 \\
\hline Arugula & 5,005 & 2,007 & 110 & 0.77 & 18.2 \\
\hline Mustard & 865 & 329 & 20 & 0.13 & 16.5 \\
\hline Molasses & 1,076 & 387 & 11 & 0.15 & 35.2 \\
\hline Feather meal & 989 & 495 & 148 & 0.19 & 3.3 \\
\hline Weeds & 440 & 132 & 9 & 0.05 & 14.7 \\
\hline ASD mustard/arugula & 7,136 & 2,931 & 315 & 1.13 & 9.3 \\
\hline Arugula & 5,000 & 2,000 & 125 & 0.77 & 16.0 \\
\hline Mustard & 806 & 306 & 23 & 0.12 & 13.3 \\
\hline Feather meal & 1,075 & 538 & 161 & 0.21 & 3.3 \\
\hline Weeds & 255 & 87 & 6 & 0.03 & 14.5 \\
\hline ASD cereal rye + molasses & 11,754 & 4,458 & 353 & 1.68 & 12.6 \\
\hline Cereal rye & 9,636 & 3,565 & 193 & 1.34 & 18.5 \\
\hline Molasses & 1,076 & 387 & 11 & 0.15 & 35.2 \\
\hline Feather meal & 989 & 495 & 148 & 0.19 & 3.3 \\
\hline Weeds & 53 & 11 & 1 & 0.00 & 11.0 \\
\hline ASD cereal rye & 10,491 & 4,208 & 350 & 1.60 & 12.0 \\
\hline Cereal rye & 9,290 & 3,623 & 186 & 1.38 & 19.5 \\
\hline Feather meal & 1,075 & 538 & 161 & 0.21 & 3.3 \\
\hline Weeds & 126 & 47 & 3 & 0.01 & 15.7 \\
\hline
\end{tabular}

${ }^{\mathrm{z}}$ Based on an application area of $16.4 \mathrm{~m}^{2}(1.8 \mathrm{~m} \times 9.1 \mathrm{~m})$.

${ }^{\mathrm{y}}$ Based on soil incorporation to $20-\mathrm{cm}$ depth.

${ }^{\mathrm{x}} \mathrm{C}: \mathrm{N}$ ratio equals $\mathrm{TC}$ divided by $\mathrm{TN}$.

${ }^{w}$ Represents contribution of applied feather meal.

ASD $=$ anaerobic soil disinfestation.

redox potential (CEh). Critical redox potential was calculated using the formula: $\mathrm{CEh}=$ $595 \mathrm{mV}-(60 \mathrm{mV} \times$ soil $\mathrm{pH})$ with soil $\mathrm{pH}$ (i.e., $\left.\mathrm{pH}_{\mathrm{CaCl} 2}+0.6\right)$ determined at the termination of ASD treatment (Butler et al., $2012 b)$. For values below CEh, the absolute value of the difference between each hourly redox value and CEh was summed to give a measure of accumulated anaerobic soil conditions over a 3-week treatment period. Similar to concepts underlying degree-day or phenology models, accumulated anaerobic conditions over the length of ASD treatment could potentially indicate when ASD treatments will be successful in controlling key pests (Shennan et al., 2011).

At the termination of soil treatments (3 May 2011 and 24 Apr. 2012), soil cores were collected from each bed and analyzed as described previously. Because of hail damage to plastic mulch on 27 Apr. 2011, a second layer of plastic was placed overall beds on 6 May 2011. On 10 May 2011 and 25 Apr. 2012, tomato transplants (Solanum lycopersicum L. 'Red Defender'; Reimer Seeds, Mount Holly, $\mathrm{NC}$ ) were planted in one randomly selected half of each block with bell pepper transplants (Capsicum annum L. 'Red Knight X3R'; Johnny's Selected Seeds, Winslow, $\mathrm{ME}$ ) planted in the remaining half (10 May 2011 and 2 May 2012). Tomatoes were planted at $46-\mathrm{cm}$ spacing in one row (10 plants per bed), whereas peppers were planted $31 \mathrm{~cm}$ between and within a double row per bed (32 plants per bed). No herbicides were applied for weed control. Insect pests were controlled with applications of pyrethrum (PyGanic $^{\circledR}$ Crop Protection EC 1.4; Arbico Organics, Oro Valley, AZ) and extract of neem oil (70\% neem oil; Monterey Lawn and Garden Products, Fresno, CA) as necessary. At first harvest, recently matured leaves were collected from each treatment, dried at $65{ }^{\circ} \mathrm{C}$, and $\mathrm{TN}$ determined by combustion as described previously.

Weed populations (to species) emerging from bell pepper planting holes were counted and removed throughout the growing season on a weekly basis and then summed. Populations of Rhizoctonia solani were assessed at planting by placing 20 birch toothpicks in the soil at the base of plants (10 pepper and 10 tomato plants) in each plot using methods described by Paulitz and Schroeder (2005). Toothpicks were removed after $48 \mathrm{~h}$ and plated onto semiselective media with propagules/gram soil derived based on the toothpick surface area and soil bulk density.

Tomatoes and peppers were harvested and graded according to USDA standards (USDA-AMS, 2005a, 2005b). In 2011, harvest for both bell pepper and tomatoes occurred once a week during mid- to late July. In 2012, harvest began in mid-July for tomatoes and in mid-August for peppers. Tomatoes were harvested at the breaker stage, whereas peppers were harvested based on predominate (greater than $75 \%$ ) red color. At the end of the season, all green fruit were harvested and included in total yield estimates. Fruit were harvested from the center six tomato plants and all pepper plants with the exception of the plants at the end of each row. Yields were converted to $\mathrm{kg} \cdot \mathrm{ha}^{-1}$ based on an estimate of $5467 \mathrm{~m}$ linear bed/ha (1.83-m between-bed spacing, on center). Soil samples were also taken at first harvest and analyzed as described previously.

Data were analyzed using the mixed procedure in SAS 9.2 (SAS Institute Inc., Cary, 
NC). The effect of treatment, year (or sampling in the case of soil $\mathrm{N}$ and soil $\mathrm{pH}$ ), and the interaction of treatment and year (or sampling) were considered as fixed effects and the effect of block and the interaction of block and year considered as random effects. Degrees of freedom were calculated according to a Satterthwaite approximation. Main effects, interactions, and differences between means were considered significant at $P<0.05$. Least-square means were separated using Fisher's least significant difference procedure.

Where needed, data were transformed to meet model normality assumptions. All reported means are non-transformed. Accumulated anaerobic conditions data were transformed (square root) before analysis of variance (ANOVA) as a result of a nonnormal distribution. Furthermore, analysis of data for potential outliers identified two values which on examination of raw data logger output were determined to have been the result of redox electrode malfunction and thus were removed from the analysis. Data removed represented one probe of two in respective plots in 2012. Population data for $R$. solani colonizing toothpicks placed in the soil at planting and weed population data were also transformed (square root and $\log _{10}$, respectively) before ANOVA.

\section{Results}

Amendment biomass, carbon, and nitrogen. In 2011, total biomass incorporated for soil treatments ranged from $1,075 \mathrm{~kg} \cdot \mathrm{ha}^{-1}$ for the untreated control to $11,754 \mathrm{~kg} \cdot \mathrm{ha}^{-1}$ for ASD cereal rye + molasses (Table 2 ). In 2012, total biomass ranged from $1,075 \mathrm{~kg} \cdot \mathrm{ha}^{-1}$ for the untreated control to $21,770 \mathrm{~kg} \cdot \mathrm{ha}^{-1}$ for ASD mustard/arugula + molasses (Table 3 ). The primary difference between seasons was the lower biomass contribution of the mustard cover crop during 2011 as a result of winterkill influenced by the earlier planting date and colder winter conditions compared with 2012. The ratio of $\mathrm{C}$ in amendments incorporated to the estimated soil volume to a 20-cm depth ranged from $0.21 \mathrm{mg} \mathrm{C} / \mathrm{g}$ soil for the untreated control to 1.60 and $1.68 \mathrm{mg} \mathrm{C} / \mathrm{g}$ soil in the ASD cereal rye (with or without molasses, respectively) treatments in 2011 (Table 2). In 2012, this value ranged from $0.21 \mathrm{mg} \mathrm{C} / \mathrm{g}$ soil (untreated control) to $3.14 \mathrm{mg}$ C/g soil (ASD mustard/arugula + molasses; Table 3). Ratios of $\mathrm{C}$ to $\mathrm{N}$ in incorporated amendment mixtures and aboveground cover crop biomass (i.e., TC divided by $\mathrm{TN}$ ) were generally low (less than 16) in all treatments (Tables 2 and 3).

Soil properties. There were significant treatment $(P=0.001)$ and year $(P=0.026)$ effects on accumulated anaerobic conditions, and no significant interaction effect of treatment and year $(P=0.28)$. Averaged across year, the highest accumulated anaerobic conditions were observed in the ASD cereal rye (with or without molasses), ASD molasses, and ASD mustard/arugula + molasses treatments, which were greater than the untreated and biofumigant controls (Fig. 1). In general,
Table 3. Total biomass, carbon (TC) and nitrogen (TN) content, and C:N ratio of soil amendments and incorporated abovegroundcover crop biomass, Spring 2012.

\begin{tabular}{|c|c|c|c|c|c|}
\hline & \multicolumn{5}{|c|}{2012} \\
\hline & $\overline{\text { Biomass }^{z}}$ & $\mathrm{TC}^{\mathrm{z}}$ & $\mathrm{TN}^{\mathrm{z}}$ & $\mathrm{TC}^{\mathrm{y}}$ & \multirow[b]{2}{*}{$\mathrm{C}: \mathrm{N}$ ratio $^{\mathrm{x}}$} \\
\hline & \multicolumn{3}{|c|}{ 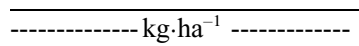 } & $\mathrm{mg} \mathrm{C/g} \mathrm{soil}$ & \\
\hline Untreated control $^{\mathrm{w}}$ & 1,075 & 538 & 161 & 0.21 & 3.3 \\
\hline Biofumigant control & 2,177 & 893 & 109 & 0.35 & 8.2 \\
\hline ASD molasses & 5,993 & 2,243 & 146 & 0.86 & 15.4 \\
\hline Molasses & 5,381 & 1,937 & 54 & 0.74 & 35.9 \\
\hline Feather meal & 612 & 306 & 92 & 0.12 & 3.3 \\
\hline ASD mustard/arugula + molasses & 21,770 & 8,158 & 517 & 3.14 & 15.8 \\
\hline Arugula & 7,928 & 2,807 & 159 & 1.08 & 17.7 \\
\hline Mustard & 9,173 & 3,688 & 147 & 1.42 & 25.1 \\
\hline Molasses & 1,076 & 387 & 11 & 0.15 & 35.2 \\
\hline Feather meal & 989 & 495 & 148 & 0.19 & 3.3 \\
\hline Weeds $^{\mathrm{v}}$ & 2,604 & 781 & 52 & 0.30 & 15.0 \\
\hline ASD mustard/arugula & 20,552 & 7,661 & 570 & 2.96 & 13.4 \\
\hline Arugula & 8,606 & 3,047 & 172 & 1.18 & 17.7 \\
\hline Mustard & 9,060 & 3,460 & 192 & 1.33 & 18.0 \\
\hline Feather meal & 1,075 & 538 & 161 & 0.21 & 3.3 \\
\hline Weeds & 1,811 & 616 & 45 & 0.24 & 13.7 \\
\hline ASD cereal rye + molasses & 12,505 & 4,787 & 403 & 1.84 & 11.9 \\
\hline Cereal rye & 8,967 & 3,596 & 215 & 1.38 & 16.7 \\
\hline Molasses & 1,076 & 387 & 11 & 0.15 & 35.2 \\
\hline Feather meal & 989 & 495 & 148 & 0.19 & 3.3 \\
\hline Weeds & 1,473 & 309 & 29 & 0.12 & 10.7 \\
\hline ASD cereal rye & 13,419 & 5,266 & 448 & 1.99 & 11.8 \\
\hline Cereal rye & 10,079 & 3,890 & 242 & 1.46 & 16.1 \\
\hline Feather meal & 1,075 & 538 & 161 & 0.21 & 3.3 \\
\hline Weeds & 2,265 & 838 & 45 & 0.32 & 18.6 \\
\hline
\end{tabular}

${ }^{2}$ Based on an application area of $16.4 \mathrm{~m}^{2}(1.8 \mathrm{~m} \times 9.1 \mathrm{~m})$.

${ }^{\mathrm{y}}$ Based on soil incorporation to 20 -cm depth.

${ }^{\mathrm{x}} \mathrm{C}: \mathrm{N}$ ratio equals TC divided by TN.

${ }^{\text {w }}$ Represents contribution of applied feather meal.

${ }^{\mathrm{T}} \mathrm{TC}$ and TN for weed species in 2012 estimated based on TC and TN concentrations of weed biomass in 2011.

$\mathrm{ASD}=$ anaerobic soil disinfestation.

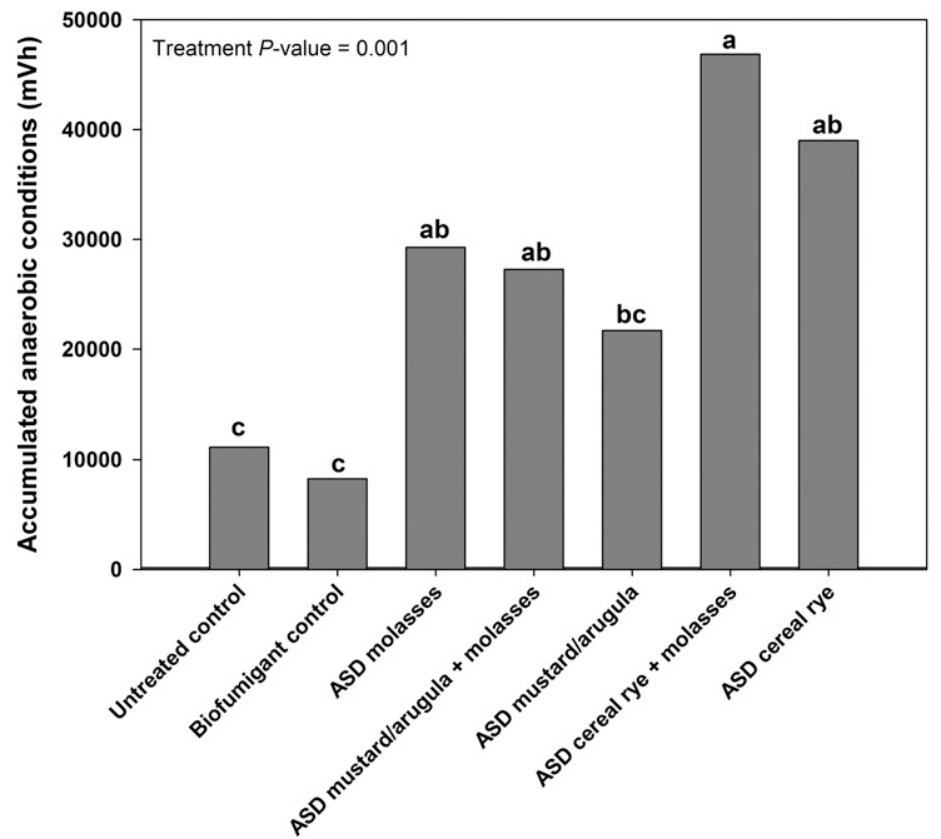

Fig. 1. Mean accumulated anaerobic conditions $\left(\mathrm{mV} \cdot \mathrm{h}^{-1}\right)$ as affected by treatment. Values represent pooled means of treatments in 2011 and 2012. Means indicated by different letters are significantly different, $P<0.05$. Data were square root-transformed before analysis. Reported means are non-transformed. 
across all treatments there was a greater accumulation of anaerobic conditions during the second season of the study $(35,590 \mathrm{vs}$. $16,818 \mathrm{mV} \cdot \mathrm{h}^{-1}$ ).

Soil $\mathrm{pH}$ was significantly affected by treatment $(P<0.001)$ and sampling time $(P=$ $0.003)$ with no significant interaction of treatment and sampling time $(P=0.99)$. However, the change in soil $\mathrm{pH}$ during the treatment period differed markedly in the two seasons with increases in soil $\mathrm{pH}$ observed during treatment in 2011 and decreases observed in 2012 (Table 4). In 2011, the highest posttreatment soil $\mathrm{pH}$ values were observed for the ASD cereal rye (with or without molasses) treatments (7.3), which were greater than ASD mustard/arugula, ASD molasses, biofumigant control, and untreated control treatments (7.0 or less; Table 4). In 2012, post-treatment $\mathrm{pH}$ was highest in the ASD cereal rye treatment (6.7), which was greater than the ASD molasses, biofumigant control, and untreated control treatments (less than 6.4). Soil $\mathrm{pH}$ increased from pre-treatment to post-treatment in 2011 with significant increases of 0.3 to $0.4 \mathrm{pH}$ units for all treatments except the biofumigant control (Table 4). In 2012, a general decrease in soil $\mathrm{pH}$ of 0.2 to $0.3 \mathrm{pH}$ units was observed from pre-treatment to post-treatment, which was significant for the biofumigant control, ASD mustard/arugula, and ASD cereal rye ( \pm molasses) treatments. Over both years of the study, the change in $\mathrm{pH}$ values (pre-treatment to post-treatment) was significantly related to accumulated anaerobic conditions $(P=0.04)$.

Gravimetric soil moisture content determined from soil samples taken at treatment termination did not differ by treatment $(P=$ $0.09)$ or year $(P=0.41$; data not shown). Similarly, no treatment differences $(P=0.57)$ were observed in volumetric soil moisture content determined during the treatment period. However, volumetric water content was higher during treatment in $2012(P<0.001$; $\left.0.32 \mathrm{~cm}^{3} \cdot \mathrm{cm}^{-3}\right)$ than in $2011\left(0.20 \mathrm{~cm}^{3} \cdot \mathrm{cm}^{-3}\right)$. Mean soil temperature during the treatment period did not differ among treatments $(P=$ $0.90)$ or year $(P=0.39)$, averaging $20.8^{\circ} \mathrm{C}$ in 2011 and $20.6{ }^{\circ} \mathrm{C}$ in 2012 .

Total soil inorganic $\mathrm{N}$ (i.e., $\mathrm{NH}_{4}-\mathrm{N}, \mathrm{NO}_{3}-$ $\mathrm{N}$, and $\left.\mathrm{NO}_{2}-\mathrm{N}\right)$ was significantly affected by treatment $(P=0.005$; Fig. 2$)$ and sampling time $(P<0.0001 ;$ Fig. 3$)$. The interaction of treatment and sampling time was not significant $(P=0.12)$. Throughout the study, the highest mean total soil inorganic $\mathrm{N}$ was observed from the ASD mustard/arugula (with or without molasses), ASD cereal rye + molasses, and untreated control treatments (greater than $34 \mathrm{mg} \mathrm{N} / \mathrm{kg}$ soil) and least from the ASD molasses and biofumigant control treatments $(25 \mathrm{mg} \mathrm{N} / \mathrm{kg}$ soil; Fig. 2). With the exception of the posttreatment soil sampling in 2011, total soil inorganic $\mathrm{N}$ averaged less than $30 \mathrm{mg} \mathrm{N} / \mathrm{kg}$ soil when averaged across soil treatments (Fig. 3). At that sampling, soil inorganic N was elevated to near $90 \mathrm{mg} \mathrm{N} / \mathrm{kg}$ soil. Across sampling times and treatments, soil inorganic $\mathrm{N}$ was primarily comprised of $\mathrm{NO}_{3}+\mathrm{NO}_{2}-\mathrm{N}$

Table 4. Mean soil $\mathrm{pH}$ as affected by soil treatment, pre- and post-treatment, and $\mathrm{pH}$ change from pre- to post-treatment, 2011 and 2012.

\begin{tabular}{|c|c|c|c|c|c|c|}
\hline & \multicolumn{2}{|c|}{ Pre-treatment } & \multicolumn{2}{|c|}{ Post-treatment } & \multicolumn{2}{|c|}{ Soil $\mathrm{pH}$ change ${ }^{\mathrm{z}}$} \\
\hline & 2011 & 2012 & 2011 & 2012 & 2011 & 2012 \\
\hline & \multicolumn{4}{|c|}{ 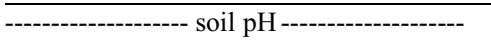 } & \multicolumn{2}{|c|}{-------pH units ------ } \\
\hline Untreated control & 6.6 & $6.6 \mathrm{~b}^{\mathrm{y}}$ & $6.9 \mathrm{~b}$ & $6.3 \mathrm{bc}$ & $+0.3^{*}$ & -0.3 \\
\hline Biofumigant control & 6.6 & $6.5 \mathrm{~b}$ & $6.8 \mathrm{~b}$ & $6.2 \mathrm{c}$ & +0.2 & $-0.3 *$ \\
\hline ASD molasses & 6.5 & $6.6 \mathrm{~b}$ & $6.8 \mathrm{~b}$ & $6.4 \mathrm{bc}$ & $+0.3^{*}$ & -0.2 \\
\hline ASD mustard/arugula + molasses & 6.8 & $6.7 \mathrm{ab}$ & $7.1 \mathrm{ab}$ & $6.6 \mathrm{ab}$ & $+0.3^{*}$ & -0.2 \\
\hline ASD mustard/arugula & 6.7 & $6.7 \mathrm{ab}$ & $7.0 \mathrm{~b}$ & $6.4 \mathrm{abc}$ & $+0.3^{*}$ & $-0.3^{*}$ \\
\hline ASD cereal rye + molasses & 6.9 & $6.9 \mathrm{a}$ & $7.3 \mathrm{a}$ & $6.6 \mathrm{ab}$ & $+0.4^{*}$ & $-0.3^{*}$ \\
\hline ASD cereal rye & 6.9 & $6.9 \mathrm{a}$ & $7.3 \mathrm{a}$ & $6.7 \mathrm{a}$ & $+0.4^{*}$ & $-0.2^{*}$ \\
\hline Treatment $P$ value & 0.067 & 0.031 & 0.014 & 0.041 & N/A & N/A \\
\hline
\end{tabular}

${ }^{2}$ Post-treatment soil $\mathrm{pH}$ minus pre-treatment soil $\mathrm{pH}$.

${ }^{\mathrm{y}}$ Within columns, means indicated by different letters are significantly different, $P<0.05$.

*Within each soil treatment, significant change in soil $\mathrm{pH}$ following treatment at $P<0.05$.

$\mathrm{ASD}=$ anaerobic soil disinfestation; N/A = not applicable.

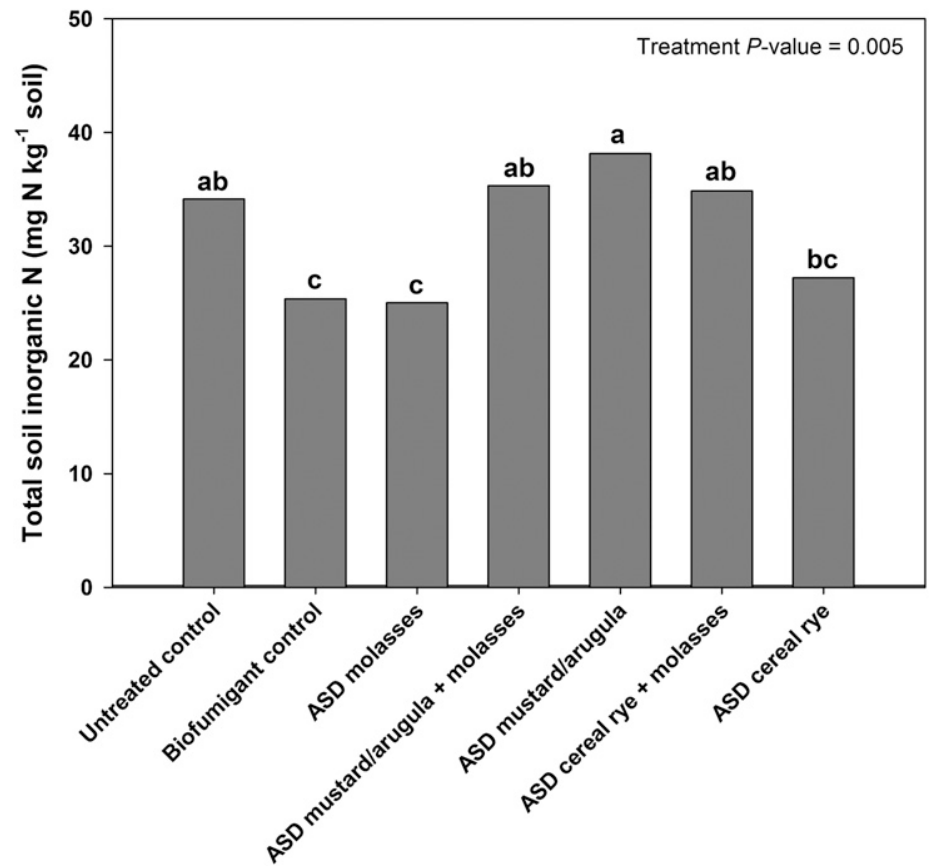

Fig. 2. Mean total soil inorganic nitrogen $(\mathrm{N})$ as affected by treatment. Values represent pooled means of sampling times in 2011 and 2012. Means indicated by different letters are significantly different, $P<0.05$.

( $71 \%$ to $93 \%$ of total inorganic $\mathrm{N}$; data not shown).

Weed and pathogen dynamics. There was a significant effect of treatment $(P=0.01)$, but no significant effect of year $(P=0.88)$ or interaction of treatment and year $(P=0.38)$ on populations of $R$. solani. When averaged across year, mean populations of $R$. solani were less than the untreated control in the biofumigant control, which was equivalent to the ASD mustard/arugula and ASD cereal rye treatments (Fig. 4). Populations of $R$. solani in ASD treatments including molasses amendment were equivalent to the untreated control.

Numbers of monocot weeds emerging from bell pepper planting holes was significantly affected by treatment $(P=0.0004)$, but not year $(P=0.72)$ and no interaction effect was observed $(P=0.34$; data not shown). Numbers of monocot weeds were lower than the untreated control in the ASD cereal rye and ASD mustard/arugula (with or without molasses) treatments, although even in the untreated control, monocot weed populations were relatively low at less than $1 \mathrm{weed} / \mathrm{m}$ bed length emerging over the course of the growing season. Dicot weed populations did not differ among treatments $(P=0.38)$ or year $(P=0.09)$.

Crop performance. Total tomato yield (marketable + culled fruit) was not significantly affected by treatment $(P=0.09)$, year $(P=0.16)$, and no interaction was observed $(P=0.25)$. Averaged across seasons, yields ranged from $81,417 \mathrm{~kg} \cdot \mathrm{ha}^{-1}$ for ASD 


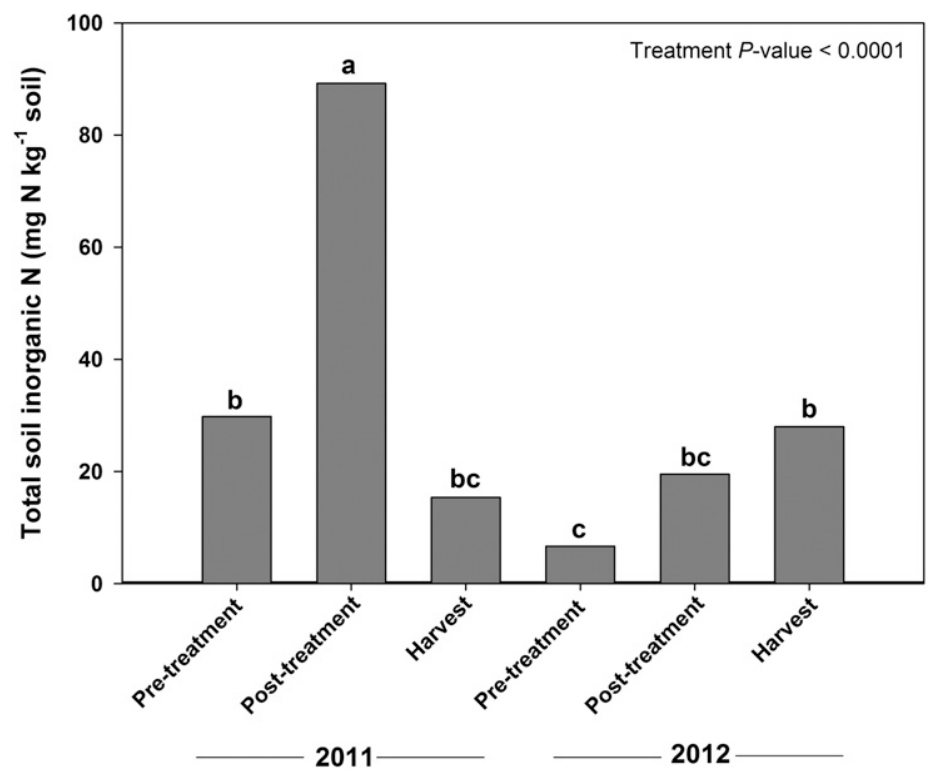

Fig. 3. Mean total soil inorganic nitrogen (N) as affected by sampling time in 2011 and 2012. Values represent pooled means by soil treatment at each sampling time. Means indicated by different letters are significantly different, $P<0.05$.

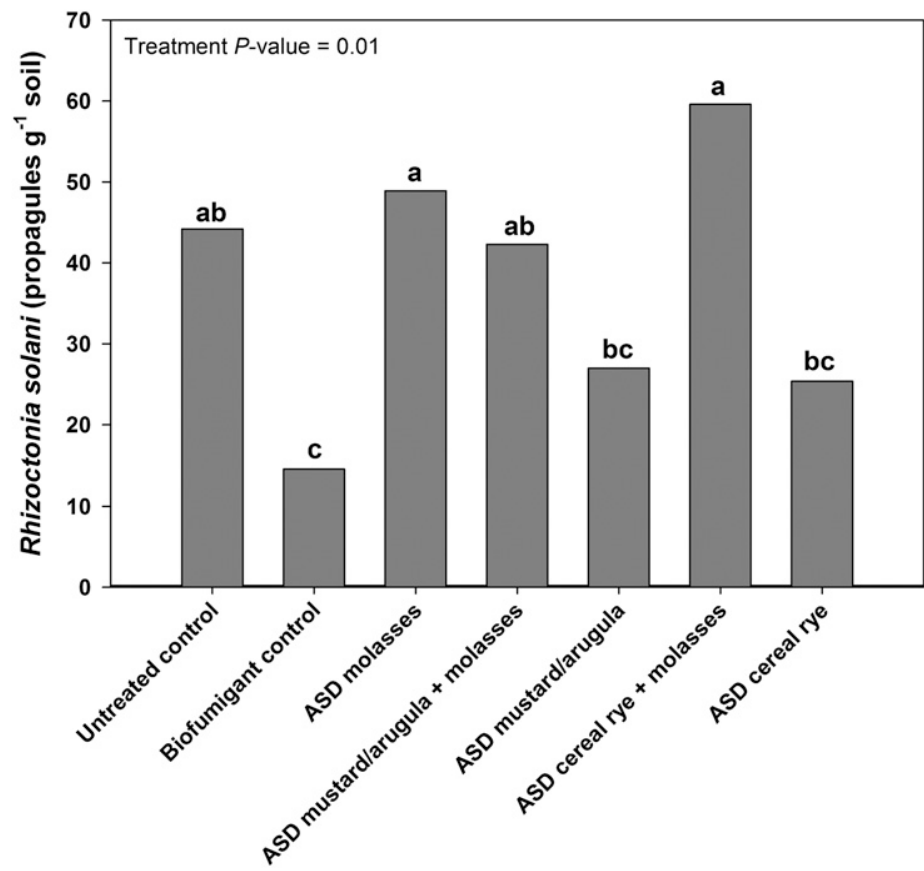

Fig. 4. Mean population of Rhizoctonia solani colonizing birch toothpicks immediately after soil treatment. Values represent pooled means of 2011 and 2012 data. Means indicated by different letters are significantly different, $P<0.05$. Data were square root-transformed before analysis. Reported means are non-transformed.

mustard/arugula to $91,923 \mathrm{~kg} \cdot \mathrm{ha}^{-1}$ for the ASD molasses treatment (Fig. 5). Total marketable fruit yield (USDA No. 1, 2, and 3 ) also did not differ among treatments $(P=$ $0.74)$, ranging from $37,224 \mathrm{~kg} \cdot \mathrm{ha}^{-1}$ for ASD cereal rye + molasses to $43,133 \mathrm{~kg} \cdot \mathrm{ha}^{-1}$ for ASD molasses (data not shown). There were also no differences in culled tomato fruit weights among treatments, which ranged from $33 \%$ to $39 \%$ of total yields. Tomato leaf tissue total $\mathrm{N}$ content did not differ among treatments $(P=0.90)$ but did differ by year $(P<0.0001)$. Tomato leaf $\mathrm{N}$ concentration averaged $4.8 \mathrm{cg} \mathrm{N} / \mathrm{g}$ in 2011 and $6.3 \mathrm{cg}$ $\mathrm{N} / \mathrm{g}$ in 2012.

Like with tomato, total bell pepper yield (marketable + culled fruit) was not significantly affected by treatment $(P=0.20)$, year $(P=0.16)$, or the interaction $(P=0.47)$. Averaged across seasons, total bell pepper yields ranged from $28,811 \mathrm{~kg} \cdot \mathrm{ha}^{-1}$ for ASD cereal rye + molasses to $36,323 \mathrm{~kg} \cdot \mathrm{ha}^{-1}$ for ASD mustard/arugula (Fig. 6). Similarly, there were no differences among treatments in total marketable yields or culled fruit weights (data not shown). Across seasons, total marketable red bell pepper (USDA Fancy, No. 1 and No. 2) yields ranged from $6131 \mathrm{~kg} \cdot \mathrm{ha}^{-1}$ to $9152 \mathrm{~kg} \cdot \mathrm{ha}^{-1}$. Bell pepper leaf tissue $\mathrm{N}$ was not significantly related to treatment $(P=0.36)$ but did differ between seasons $(P=0.047)$ with slightly higher $\mathrm{N}$ concentrations in 2012 than $2011(4.4 \mathrm{cg} \mathrm{N} / \mathrm{g}$ and $4.1 \mathrm{cg} \mathrm{N} / \mathrm{g}$, respectively).

\section{Discussion}

The anaerobic soil conditions that accumulated during the ASD treatments in this study were similar to those reported in previous ASD studies. Butler et al. (2012b) reported accumulated anaerobic values $\left(\mathrm{mV} \cdot \mathrm{h}^{-1}\right)$ for a molasses ASD treatment below 5,000 $\mathrm{mV} \cdot \mathrm{h}^{-1}$ and near $30,000 \mathrm{mV} \cdot \mathrm{h}^{-1}$ in Years 1 and 2 of a Florida field study. A similar pattern of increased accumulation of anaerobic conditions was observed in our study from 2011 to 2012 with the molasses treatment specifically increasing from 11,597 $\mathrm{mV} \cdot \mathrm{h}^{-1}$ to $46,923 \mathrm{mV} \cdot \mathrm{h}^{-1}$. The increase in anaerobic activity in the second year may have been influenced by adaptation of the soil microbial community to large inputs of labile C. In California, Shennan et al. (2011) reported that a threshold of $50,000 \mathrm{mV} \cdot \mathrm{h}^{-1}$ at $25{ }^{\circ} \mathrm{C}$ soil temperature is necessary for control of $V$. dahliae and offers the only reported threshold to gauge the effectiveness of ASD treatments for pathogen control. In 2011, treatments in our study did not reach this threshold; whereas in 2012, the ASD cereal rye + molasses treatment was the only treatment above this threshold. However, mean soil temperatures during ASD treatment in 2011 and 2012 were $\approx 20{ }^{\circ} \mathrm{C}$ rather than $25^{\circ} \mathrm{C}$, and temperature has been shown to impact the effect of treatment on pathogen control (Stapleton et al., 2010).

Seasonal biomass variability could have impacted accumulation of anaerobic conditions; i.e., we would expect greater anaerobic conditions with increased $\mathrm{C}$ available to support soil microbial growth and respiration. However, the influence of the nearly 3 -fold increase in cover crop biomass $\mathrm{C}$ of the ASD mustard/arugula treatments in 2012 did not correlate to differences in cumulative $\mathrm{mV} \cdot \mathrm{h}^{-1}$ values. Whereas a general increase was observed in cumulative $\mathrm{mV} \cdot \mathrm{h}^{-1}$ from 2011 to 2012 , this was also the case for treatments without increased amendment rates in 2012 (i.e., untreated control, ASD molasses) because there was not a significant interaction of treatment and year. The general increase in accumulated anaerobic conditions as compared with the untreated (unamended) control is consistent with results reported by Butler et al. (2012a, 2012b) in field and greenhouse studies. At the same time, variability existing in these measures between treatments within studies and between studies 


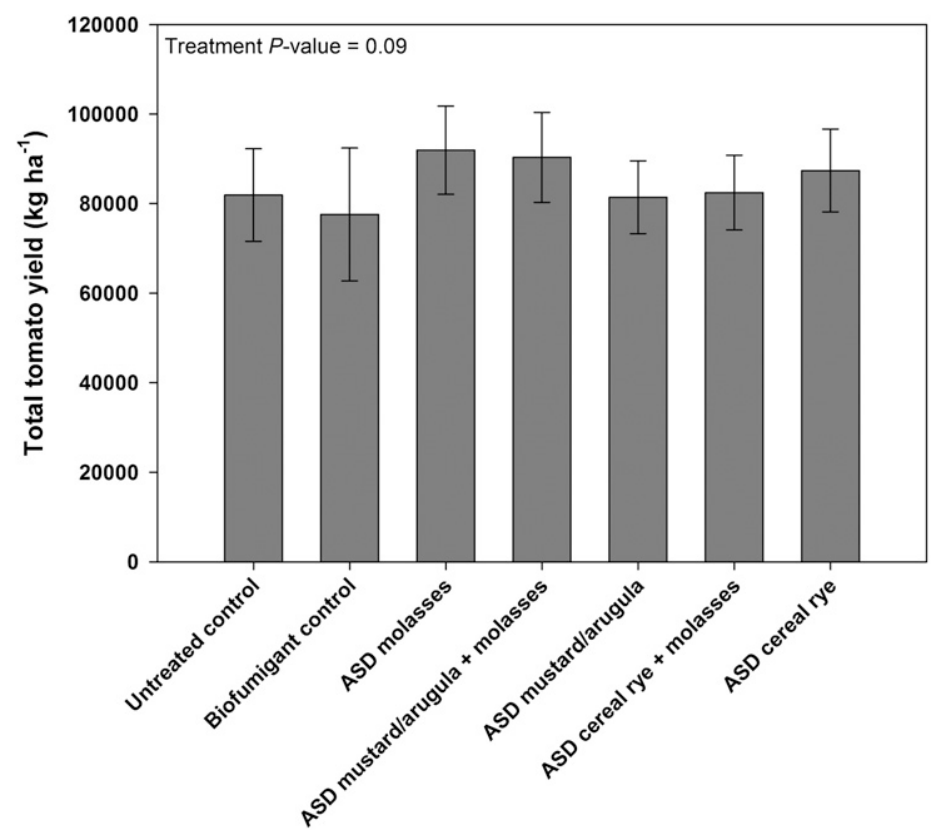

Fig. 5. Mean total tomato yield as affected by treatment. Values represent pooled means of 2011 and 2012 data. Error bars represent $95 \%$ confidence intervals.

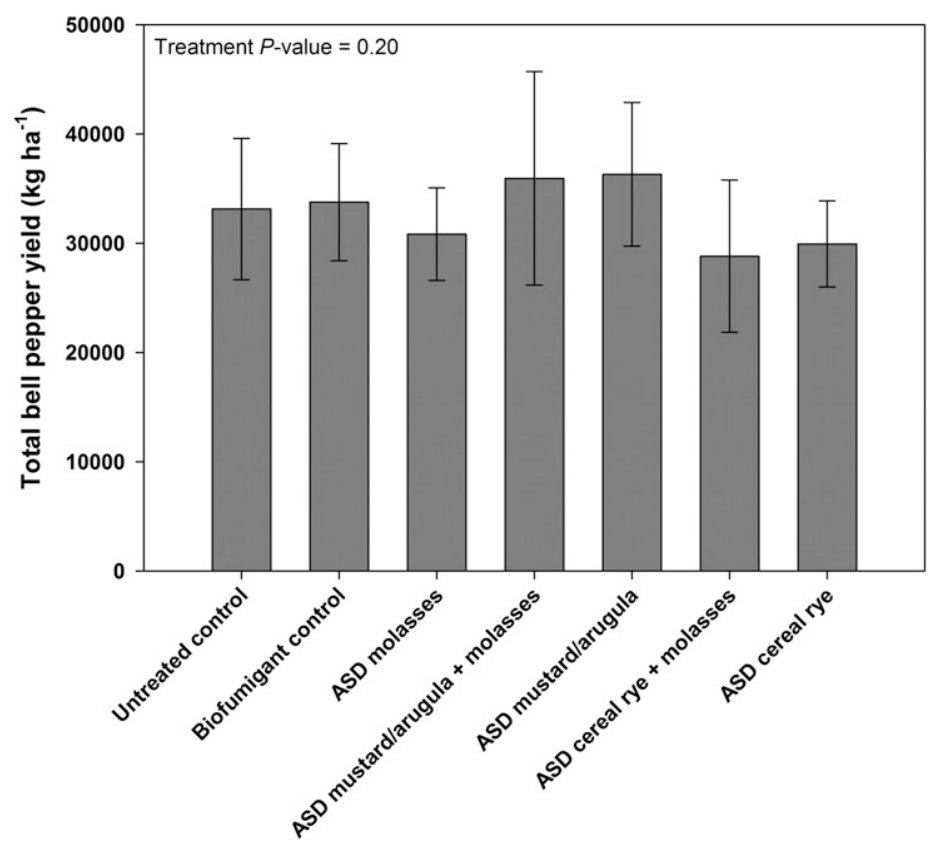

Fig. 6. Mean total bell pepper yield as affected by treatment. Values represent pooled means of 2011 and 2012 data. Error bars represent $95 \%$ confidence intervals.

may partly be a function of measurement technique given the heterogeneous nature of the soil matrix and the fact that redox electrodes are only able to capture processes occurring at a microsite scale $\left(\mathrm{mm}^{3}\right.$; Fiedler et al., 2007).

A decline in soil $\mathrm{pH}$ after ASD is a potential indicator that organic acids important to pest control are being created through the anaerobic decomposition of the $\mathrm{C}$ amendments (Momma, 2008). In 2011, there was no measurable decline in soil $\mathrm{pH}$ values from pre- to post-treatment with $\mathrm{pH}$ instead increasing in the range of 0.3 to 0.4 units across treatments. This increase in soil $\mathrm{pH}$ is not unexpected when large amounts of organic matter are incorporated into acidic soils and anaerobic conditions are limited (Marschner and Noble, 2000; Pocknee and Sumner, 1997; Sakala et al., 2004; Xu et al., 2006), primarily as a result of the release of basic cations during organic matter decomposition. In 2012, declines in soil $\mathrm{pH}$ values ( 0.2 to 0.3 units) were observed from pre-treatment to post- treatment, although not significantly so in all treatments. Overall, the treatments were more anaerobic in 2012 so the decline in soil $\mathrm{pH}$ could indicate a greater contribution of organic acids developing under improved anaerobic conditions.

The predominance of $\mathrm{NO}_{3}+\mathrm{NO}_{2}-\mathrm{N}$ in soils throughout our study suggests that unlike many soil fumigants (Chen et al., 1991), ASD treatment as implemented in this study is unlikely to negatively impact nitrifying soil bacteria. Another potential concern with ASD treatment is that when using substantial amounts of biomass to supply labile $\mathrm{C}$ to soil microbes, there is potential for crop $\mathrm{N}$ limitation when available $\mathrm{N}$ is not sufficient for microbial metabolism of added labile $\mathrm{C}$, whether because of low soil $\mathrm{N}$ or low $\mathrm{N}$ in soil amendments (i.e., high amendment C:N ratio). Whitmore (1996), synthesizing a number of primary sources, reported that $\mathrm{C}: \mathrm{N}$ ratios of organic soil amendments below $\approx 20: 1$ to $25: 1$ were unlikely to result in $\mathrm{N}$ immobilization. This is consistent with soil $\mathrm{N}$ dynamics observed in our study which had relatively low $\mathrm{C}: \mathrm{N}$ ratios of amendments for all treatments (less than 16:1). However, treatment differences in soil inorganic $\mathrm{N}$ were observed in our study with the lowest inorganic $\mathrm{N}$ observed in the ASD molasses and biofumigant control treatments. This was a partial result of the lack of cover crops in these treatments during the winter seasons, which resulted in altered $\mathrm{N}$ cycling patterns and potentially increased losses compared with cover-cropped plots (Snapp et al., 2005). Although the biofumigant control treatment had less total $\mathrm{N}$ applied than the untreated control (as a result of initial $\mathrm{N}$ concentration estimates differing slightly from measured values), the depression of $\mathrm{N}$ availability in the ASD molasses treatment as compared with the untreated control suggests that even with the added feather meal to substantially lower the $\mathrm{C}: \mathrm{N}$ ratio of the molasses amendment, soil $\mathrm{N}$ availability in ASD molasses treatments is likely to differ from standard grower practices. Results presented here on the availability of $\mathrm{N}$ after ASD soil treatments will be useful to producers as they implement ASD treatments and alter fertilization practices to account for $\mathrm{N}$ mineralization or immobilization during ASD treatment. Similarly, results will assist researchers in the design of studies evaluating alternative soil disinfestation treatments including substantial organic amendment application along with treatments lacking such amendment applications. Although the impact of amendment on soil fertility (and other soil properties) is often ignored when pest control differences are the primary research objectives, it is imperative that a systems research approach be applied to these studies so that crop yield differences influenced by soil property changes are not attributed solely to differences in disinfestation potential

Whereas $R$. solani populations in ASD treatments with molasses application were greater than the biofumigant control treatment, those ASD treatments with cover crop 
residue but without molasses had equivalent populations to the biofumigant control. The use of organic amendments to control $R$. solani has shown variable results across numerous studies and is potentially linked to amendment chemical properties (Bonanomi et al., 2007, 2010). Hoitink and Boehm (1999) suggested that control of $R$. solani with organic amendments is dependent on parasitism (largely by Trichoderma spp.) and is improved through amendments high in cellulosic substances vs. those high in simple sugars, which is consistent with our results. At the same time, Blok et al. (2000) reported that inoculum survival of $R$. solani was unaffected in amended soils (broccoli or perennial ryegrass residues) unless polyethylene mulch was used to induce anaerobic conditions, indicating the importance of anaerobic decomposition of the organic amendment. The ASD mustard/arugula (with or without molasses) and biofumigant control treatments could also have influenced disease severity based on the biofumigant potential (i.e., isothiocyanates produced from the degradation of glucosinolates) in each of these treatments. Several previous studies have indicated the potential of mustard cover crop residue to control $R$. solani and other fungal pathogens (Charron and Sams, 1999; Friberg et al., 2009; Larkin and Griffin, 2007).

There is currently a lack of published studies evaluating crop yields after soil treatment by ASD. Although no significant differences in yield between ASD treatments and the untreated control were observed for either tomato or bell pepper in our study, this is not surprising when pest pressure is low and soil fertility does not differ significantly among treatments. Numerous published studies across diverse regions and crops have demonstrated that soil fumigation by $\mathrm{MeBr}$ or other chemical fumigant alternatives does not always result in a yield increase compared with untreated controls (e.g., Chellemi et al., 1997; Gerik, 2005a, 2005b; Saha et al., 2007; Yao et al., 2006; Yuen et al., 1991). It is also reasonable to speculate that studies that show no differences between MeBr alternatives and untreated controls may be underrepresented in the literature compared with those that show a treatment effect (i.e., positive results reporting bias or "file-drawer" effect; Csada et al., 1996) and that researchers typically choose sites with high pest pressure for soil disinfestation studies, if such sites are available. This suggests that study sites described in published works are likely not representative of the production sites or site years that may respond to soil fumigation or alternative disinfestation practices.

This study is the first step in defining an ASD treatment system for warm-season vegetable production that is more applicable to Tennessee and similar production environments than previous work reported in Florida, which combined ASD with soil solarization. Although crop yield differences were not observed among treatments, this study establishes management of ASD treatments in Tennessee, without soil solarization, that can contribute to high accumulations of anaerobic conditions, which do not result in yield reductions compared with an untreated control and introduce no substantial negative impacts on soil nutrients and crop nutrition. However, there is a need for further evaluation of the effectiveness of ASD treatments on pest populations over multiple site years, particularly on sites with high soilborne plant pathogen or plant parasitic nematode pressure in this region to determine if the practice would be a viable option for vegetable growers.

\section{Literature Cited}

Blok, W.J., J.G. Lamers, A.J. Termorshuizen, and G.J. Bollen. 2000. Control of soilborne plant pathogens by incorporating fresh organic amendments followed by tarping. Phytopathology 90:253-259.

Bonanomi, G., V. Antignani, M. Capodilupo, and F. Scala. 2010. Identifying the characteristics of organic soil amendments that suppress soilborne plant diseases. Soil Biol. Biochem. 42:136-144.

Bonanomi, G., V. Antignani, C. Pane, and F. Scala. 2007. Suppression of soilborne fungal diseases with organic amendments. J. Plant Pathol. 89:311-324.

Butler, D.M., N. Kokalis-Burelle, J. Muramoto, C. Shennan, T.G. McCollum, and E.N. Rosskopf. 2012a. Impact of anaerobic soil disinfestation combined with soil solarization on plant-parasitic nematodes and introduced inoculum of soilborne plant pathogens in raised-bed vegetable production. Crop Prot. 39:33-40.

Butler, D.M., E.N. Rosskopf, N. Kokalis-Burelle, J. Albano, J. Muramoto, and C. Shennan. 2012b. Exploring warm-season cover crops as carbon sources for anaerobic soil disinfestation (ASD). Plant Soil 355:149-165.

Charron, C.S. and C.E. Sams. 1999. Inhibition of Pythium ultimum and Rhizoctonia solani by shredded leaves of Brassica species. J. Amer. Soc. Hort. Sci. 124:462-467.

Chellemi, D.O., S.M. Olson, D.J. Mitchell, I. Secker, and R. McSorley. 1997. Adaptation of soil solarization to the integrated management of soilborne pests of tomato under humid conditions. Phytopathology 87:250-258.

Chen, Y., A. Gamliel, J.J. Stapleton, and T. Aviad. 1991. Chemical, physical, and microbial changes related to plant growth in disinfested soils. In: Katan, J. and J.E. DeVay (eds.). Soil solarization. CRC Press, Boca Raton, FL.

Csada, R.D., P.C. James, and R.H.M. Espie. 1996. The 'file drawer problem' of non-significant results: Does it apply to biological research? Oikos 76:591-593.

Fiedler, S., M.J. Vepraskas, and J.L. Richardson. 2007. Soil redox potential: Importance, field measurements, and observations. Adv. Agron. 94:1-54.

Friberg, H., V. Edel-Hermann, C. Faivre, N Gautheron, L. Fayolle, V. Faloya, F. Montfort, and C. Steinberg. 2009. Cause and duration of mustard incorporation effects on soil-borne plant pathogenic fungi. Soil Biol. Biochem. 41:2075-2084.

Gerik, J.S. 2005a. Drip-applied soil fumigation for freesia production. HortTechnology 15:820 824.

Gerik, J.S. 2005b. Evaluation of soil fumigants applied by drip irrigation for liatris production. Plant Dis. 89:883-887.
Goud, J.K.C., A.J. Termorshuizen, W.J. Blok, and A.H.C. van Bruggen. 2004. Long-term effect of biological soil disinfestation on Verticillium wilt. Plant Dis. 88:688-694.

Hoitink, H.A.J. and M.J. Boehm. 1999. Biocontrol within the context of soil microbial communities: A substrate-dependent phenomenon. Annu. Rev. Phytopathol. 37:427-446.

Kissel, D.E., L. Sonon, P.F. Vendrell, and R.A. Isaac. 2009. Salt concentration and measurement of soil pH. Commun. Soil Sci. Plant Anal. 40:179-187.

Kissel, D.E. and P.F. Vendrell. 2012. Soil testing: Soil $\mathrm{pH}$ and salt concentration. The University of Georgia Cooperative Extension. Circular 875. Athens, GA.

Larkin, R.P. and T.S. Griffin. 2007. Control of soilborne potato diseases using Brassica green manures. Crop Prot. 26:1067-1077.

Marschner, B. and A.D. Noble. 2000. Chemical and biological processes leading to the neutralisation of acidity in soil incubated with litter materials. Soil Biol. Biochem. 32:805-813.

Messiha, N., A. van Diepeningen, M. Wenneker, A. van Beuningen, J. Janse, T. Coenen, A Termorshuizen, A. van Bruggen, and W. Blok. 2007. Biological soil disinfestation (BSD), a new control method for potato brown rot, caused by Ralstonia solanacearum race 3 biovar 2. Eur. J. Plant Pathol. 117:403-415.

Momma, N. 2008. Biological soil disinfestation (BSD) of soilborne pathogens and its possible mechanisms. Jpn. Agr. Res. Q. 42:7-12.

Momma, N., Y. Kobara, and M. Momma. 2011. $\mathrm{Fe}^{2+}$ and $\mathrm{Mn}^{2+}$, potential agents to induce suppression of Fusarium oxysporum for biological soil disinfestation. Plant Pathol. J. 77:331-335.

Momma, N., T. Usami, Y. Amemiya, and M Shishido. 2005. Factors involved in the suppression of Fusarium oxysporum f. sp. lycopersici by soil reduction. Soil Microorg. 59: 27-33.

Momma, N., K. Yamamoto, P. Simandi, and M. Shishido. 2006. Role of organic acids in the mechanisms of biological soil disinfestation (BSD). J. Gen. Plant Pathol. 72:247-252.

Paulitz, T.C. and K.L. Schroeder. 2005. A new method for the quantification of Rhizoctonia solani and $R$. oryzae from soil. Plant Dis. 89:767-772.

Pocknee, S. and M.E. Sumner. 1997. Cation and nitrogen contents of organic matter determine its soil liming potential. Soil Sci. Soc. Amer. J. 61:86-92.

Saha, S.K., K.-H. Wang, R. McSorley, R.J. McGovern, and N. Kokalis-Burelle. 2007. Effect of solarization and cowpea cover crop on plant-parasitic nematodes, pepper yields, and weeds. Nematropica 37:51-63.

Sakala, G.M., D.L. Rowell, and C.J. Pilbeam. 2004. Acid-base reactions between an acidic soil and plant residues. Geoderma 123:219232.

Shennan, C., J. Muramoto, S. Koike, M. Bolda, O. Daugovish, M. Mochizuki, K. Klonsky, E.N. Rosskopf, N. Kokalis-Burelle, and D.M. Butler. 2011. Anaerobic soil disinfestation for suppressing Verticillium dahliae in strawberry production in California. HortScience 46:S174-S175 abstract.

Sims, G.K., T.R. Ellsworth, and R.L. Mulvaney. 1995. Microscale determination of inorganic nitrogen in water and soil extracts. Commun. Soil Sci. Plant Anal. 26:303-316.

Snapp, S.S., S.M. Swinton, R. Labarta, D. Mutch, J.R. Black, R. Leep, J. Nyiraneza, and K. O'Neil. 2005. Evaluating cover crops for benefits, costs 
and performance within cropping system niches. Agron. J. 97:322-332.

Stapleton, J.J., C.G. Summers, J.P. Mitchell, and T.S. Prather. 2010. Deleterious activity of cultivated grasses (Poaceae) and residues on soilborne fungal, nematode and weed pests. Phytoparasitica 38:61-69.

UNEP. 1987. The Montreal Protocol on substances that deplete the ozone layer. 18 Dec. 2013. $<$ http://ozone.unep.org/new_site/en/montreal_ protocol.php>.
USDA-AMS. 2005a. United States standards for grades of fresh tomatoes Agricultural Marketing Service, Washington, DC

USDA-AMS. 2005b. United States standards for grades of sweet peppers Agricultural Marketing Service, Washington, DC.

Whitmore, A.P. 1996. Modelling the release and loss of nitrogen after vegetable crops. Neth. J. Agr. Sci. 44:73-86.

Xu, J.M., C. Tang, and Z.L. Chen. 2006. The role of plant residues in $\mathrm{pH}$ change of acid soils differing in initial $\mathrm{pH}$. Soil Biol. Biochem. 38:709-719.

Yao, S., I.A. Merwin, G.S. Abawi, and J.E. Thies. 2006. Soil fumigation and compost amendment alter soil microbial community composition but do not improve tree growth or yield in an apple replant site. Soil Biol. Biochem. 38:587-599.

Yuen, G.Y., M.N. Schroth, A.R. Weinhold, and J.G. Hancock. 1991. Effects of soil fumigation with methyl bromide and chloropicrin on root health and yield of strawberry. Plant Dis. 75:416-420. 